\title{
Characteristics of Axillary Odor in the Modern Japanese Female*
}

\author{
Ayumi Kyuka**, Kasumi Maeda**, Akiko Sawada***, Maki Sawada***, \\ Tadashi Shimada ***, Takeshi Hara ***, Mayumi Shimizu** \\ ** Fundamental Research Institute, ${ }^{* * *}$ Technical Development Center, Mandom Corporation
}

In our previous study, we characterized the quality and intensity of axillary odors in Japanese males using sensory evaluation. In order to investigate sex differences in the Japanese population, we evaluated and compared axillary odors of 169 healthy Japanese individuals of both sexes. Odor intensity of females was weaker than that of males. Additionally, odor intensity of males decreased with age, which was not observed in females. A remarkable relationship between odor intensity and earwax types was observed in males, but less frequently in females. The most common axillary odor quality in our study population was a milk-like odor (type $\mathrm{M}$ ). The percentage distribution of other odor quality types varied between sexes. Notably, females with acidic odor (type A) were fewer in number than males. Odor intensity tended to correlate positively with transepidermal water loss (TEWL) value within the group of female subjects with dry-type earwax. On the other hand, odor intensity was not related to shaving frequency or depilation treatment of axillary hair removal. These results show that the factors influencing axillary odor may differ between sexes.

Key words : axillary odor, odor intensity, odor quality, sensory evaluation, sex differences, earwax, TEWL, shaving, depilation treatment

* Received, November 2, 2016; Accepted, February 24, 2017

**,*** 5-12, Juniken-cho, Chuo-ku, Osaka 540-8530, Japan

doi.org/10.5107/sccj.51.147

(C) 2017 The Society of Cosmetic Chemists of Japan 


\title{
現代日本人女性の腋臭特性とその考察* \\ 久加亜由美**, 前 田 霞**, 澤 田彰子***, 澤 田真希***, \\ 嶋田 格***, 原 武 史 ${ }^{* * *}$, 清水真由美** \\ 株式会社マンダム ${ }^{* *}$ 基盤研究所, ***技術開発センター
}

\begin{abstract}
われわれはこれまでに日本人男性の腋臭強度と臭気タイプの分類について, 官能評価で解析を行つ てきた。男性の腋臭強度は若年層で高いこと, 臭気は8タイプに分類されること等がわかっていた が, 女性の腋臭の実態は不明であった。そこで, 日本人男女計 169 名の㖵覚評価を行い, 腋臭強度と 臭気タイプを男女で比較した。その結果，女性の腋臭強度は男性よりも低く，年齢による臭気強度の 低下は女性ではみられなかった。また, 女性は男性とは異なり, 腋臭強度と耳垢性状に強い関係が認 められなかった。日本人の主な臭気タイプは男女ともミルク様であった。しかし, 臭気タイプの分布 は男女で異なり，特に女性は酸っぱい臭気の割合が低いことが明らかになった。女性の特徵に着目す ると, 腋臭強度と経表皮水分蒸散量（TEWL 值）に関係が認められた。一方で, 腋臭強度は腋毛の 処理行為亡関連が認められなかった。今後, より詳細に女性の腋臭研究を進め, 女性に適応した腋臭 ケアを提案したいと考える。
\end{abstract}

\section{1. 緒言}

日本人は欧米人と比較して体臭が少ないといわれてい る。しかし，古来日本人は体臭に対して敏感であり，かつ 体臭をネガティブにとらえることが，日本の古典文学から も知ることができる1)。

ヒトの体内で産生された代謝成分は，エクリン汗腺，ア ポクリン汗腺，皮脂腺などから汗や皮脂として皮膚上に分 泌される。汗や皮脂に含まれる成分は皮膚常在菌などによ り代謝される。代謝により発生した成分のなかには，臭気 を有する揮発性成分が存在し，体臭の原因になるといわれ ている。体臭の強度や種類に個人差があることは，日常生 活において感じることである。

体臭に個人差が生じる原因を解明するため，また，より 効果的なデオドラント製品の開発に繋げるために，われわ れは日本人男性の腋臭強度の判定と, 腋臭の臭気タイプの 分類を，腋窝を直接嗅ぐ手法で実施し，日本人男性の腋臭 特性の把握に努めてきた。これまでの研究結果から，日本 人男性の腋臭強度は加齢で低下すること, 腋臭の臭気夕イ プは 8 タイプに分類されることを明らかにした2)。日本人 男性の主な腋臭の臭気タイプはミルク様の $\mathrm{M}$ 型で，臭気 強度が低いことが特徵であった。一方，酸様の $\mathrm{A}$ 型，カ レースパイス様の $\mathrm{C}$ 型, カビ様の $\mathrm{K}$ 型の臭気タイプは臭

*2016.11.2 受付, 2017.2.24 採用

**,*** 于540-8530 大阪市中央区十二軒町 5-12
気強度が高く, 臭気の特徵から $\mathrm{C}$ 型掞よび $\mathrm{K}$ 型は腋臭症 （ワキガ）に関連する臭気タイプであると考えた。

これまで日本人男性を対象に研究を行ってきたが，2011 年に日本人男女約 6 万人を対象とした意識調查の結果, 自 身の体臭に不安をもっている女性は男性よりも $10 \%$ 以上 多く，男性よりも女性のデオドラント製品の使用率が 22\%も高いことに繋がっていることが明らかになった。女 性の体臭に関する悩みを解決するために，女性の腋臭の特 徵を理解することは重要である。

そこで，日本人女性の腋臭特性を把握するために，嗅覚 評価で, 腋臭強度の判定と臭気タイプの分類を行った。女 性の特性をより詳しく理解するため, 日本人男性の腋臭も 同時期に評価し比較した。また，体臭に影響すると報告さ れている耳垢性状3)を調查し, 腋臭との関連について解析 した。さらに, 女性に特徵的な行動である腋毛処理の方法 や頻度, 腋窩肌状態, および出産と腋臭の関係についても 調査した。

\section{2. 実験}

\section{1. 腋臭の嗅覚評価・皮膚計測}

腋臭の嗅覚評価および皮膚計測は 2014 年および 2015 年 の 7 月から 8 月に, 大阪市内の環境試験室で実施した。全 ての試験は第三者機関における倫理審査委員会の承認を得 た。

\section{2. 被 験 者}

近畿圈から募集した, 健康な日本人女性 82 名（20 歳代 
29 名, 30 歳代 16 名, 40 歳代 19 名, 50 歳代 18 名）と, 比較として, 健康な日本人男性 87 名（20 歳代 36 名, 40 歳代 51 名）を被験者とした。本実験は全ての被験者から インフォームドコンセントを得た上で実施した。

\section{3. 腋臭強度評価および臭気タイプ分類}

被験者には，腋臭の嗅覚評価 7 日前から制汗デオドラン 卜剤および香りのある製品の使用を禁止し，市販の無香料

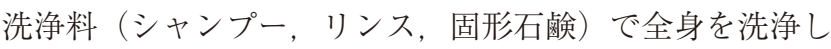
た。そのほか，腋臭評価に影響を及ぼすと考えられる，喫 煙や飲食，医薬品の服用等についても規制事項を設けた。 腋臭の嗅覚評価 $24 \pm 1$ 時間前に, 前述の無香料洗浄料で全 身を洗浄し，綿 $100 \%$ 製のシャツを着用させた。

室温 $21^{\circ} \mathrm{C}$, 相対湿度 $50 \%$ に設定した環境下で 20 分間馴 化し, 洗浄 24 時間後の腋臭の臭気を直接嗅覚で評価し た。腋臭強度は 6 段階臭気強度表示法を参考に, 0.5 刻み に 11 段階でスコア付けした $(T a b l e-1) 。$ 腋臭の臭気夕イ プは日本人男性の知見からすでに明らかになっている 8 夕 イプ（Table-2）に分類し，被験者の腋臭に含まれる各夕 イプの割合を，合計が $100 \%$ となるよう $10 \%$ 刻みでスコア 付けした。嗅覚評価は臭気判定士を含む，評価軸を標準化 した 4 名以上から成る嗅覚専門パネルで実施した。

\section{4. 皮膚計測}

嗅覚評価実施後，無香料洗浄料で全身を洗浄し， 2.3 記 載の環境下で 30 分間馴化し，女性被験者のみ腋窩および

Table-1 The levels of axillary odor intensity.

\begin{tabular}{ll}
\hline Level & \\
\hline 0 & None \\
1 & Very weak (detection threshold) \\
2 & Weak \\
3 & Easily perceptible (recognition threshold) \\
4 & Strong \\
5 & Very strong \\
\hline
\end{tabular}

Table-2 Type of odor qualities.

\begin{tabular}{ll}
\hline Type & \\
\hline $\mathrm{M}$ & Milk-like odor \\
$\mathrm{A}$ & Acidic odor \\
$\mathrm{K}$ & Moldering odor \\
$\mathrm{C}$ & Cumin-like odor \\
$\mathrm{E}$ & Steamed meat-like odor \\
$\mathrm{W}$ & Water-like odor \\
$\mathrm{F}$ & Metallic odor \\
Other & \\
\hline
\end{tabular}

上腕内側部の経表皮水分蒸散量（以下, TEWL 值）を Tewameter TM300 (Courage+Khazaka 社製)にて測定した。

\section{5. アンケートによる被験者情報の取得}

身長や体重，耳垢性状をアンケートで取得した。耳垢性 状は，「溶けたキャラメル状」「少し湿っていて黄色い」「乾 燥している」の 3 種で回答を得た。女性被験者のみ, 出産 経験, 腋毛の処理頻度や処理方法, エステティックサロン や医療機関での脱毛処理経験の有無を調査した。

\section{6. 統 計解 析}

腋臭強度や臭気夕イプの解析は, 右腋窩のデータを採用 した。2 群間の比較は Mann-Whitney's $U$ test を， 3 群間以 上の比較は Turkey-Kramer testを用いた。腋臭強度と TEWL 值の関連性は Spearmanの相関係数を求めた。全て の検定の有意水準 $p$ は 0.05 未満とした。

\section{3. 結果}

\section{1. 腋臭強度}

\subsection{1. 腋臭強度の年代および男女比較}

腋臭強度の平均值を男女年代別に示した（Table-3）。同 年代の男女比較では, 20 歳代, 40 歳代とも女性は男性よ りも約 0.5 低かった $(p<0.01)$ 。同性の年代間比較では, 男性は 20 歳代が 40 歳代よりも 0.3 高く $(p<0.05)$, 過去 の結果と一致した。一方, 女性は 20 歳代から 50 歳代にお いて腋臭強度に有意な差は認められなかった。

\subsection{2. 腋臭強度と耳垢性状の関係}

耳垢性状と腋臭強度の関係を調査した。溶けたキャラメ ル状の耳垢性状を示す男性は, 他の 2 群の男性よりも腋臭 強度は有意に高かった。この結果はこれまでの報告と一致 した。しかし, 女性では, 乾燥した耳垢性状を有する群は 他の 2 群と比較して腋臭強度が約 0.3 低かったが，有意な 差は認められなかった (Fig. -1$)$ 。

\section{2. 腋臭タイプ}

腋臭タイプの分布を 20 歳代および 40 歳代の結果から求 めた（Fig.-2）。男女いずれにおいても，日本人の主な腋

Table-3 Axillary odor intensity.

\begin{tabular}{lcc}
\hline & Age & $\begin{array}{c}\text { Odor intensity } \\
\text { (means } \pm \text { S.D. })\end{array}$ \\
\hline Males & $20 \mathrm{~s}$ & $2.9 \pm 0.51$ \\
& $40 \mathrm{~s}$ & $2.6 \pm 0.73$ \\
\hline Females & $20 \mathrm{~s}$ & $2.3 \pm 0.37$ \\
& $30 \mathrm{~s}$ & $2.6 \pm 0.55$ \\
& $40 \mathrm{~s}$ & $2.1 \pm 0.50$ \\
& $50 \mathrm{~s}$ & $2.4 \pm 0.54$ \\
\hline
\end{tabular}




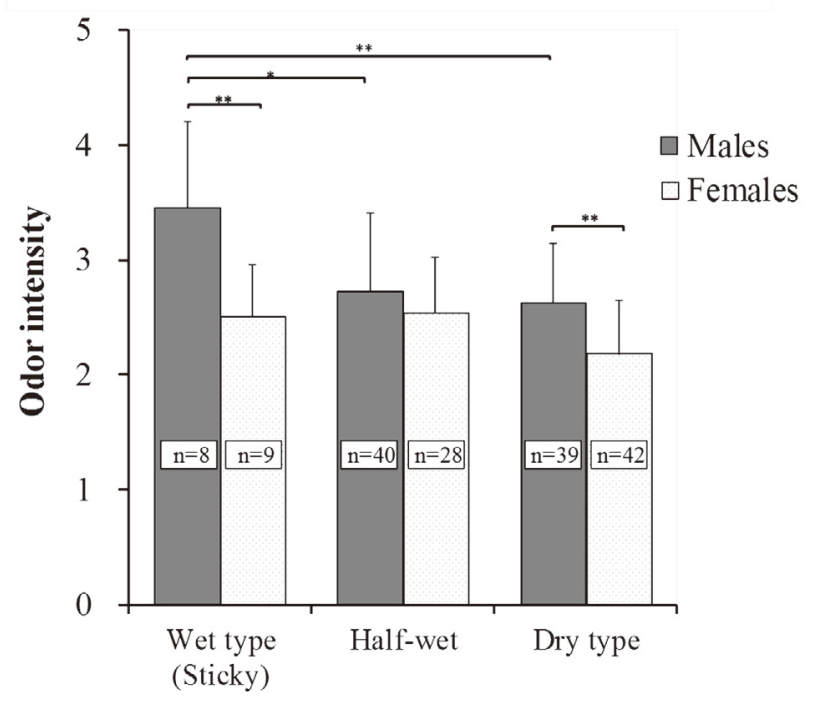

Fig.-1 Relationship between odor intensity and earwax types.

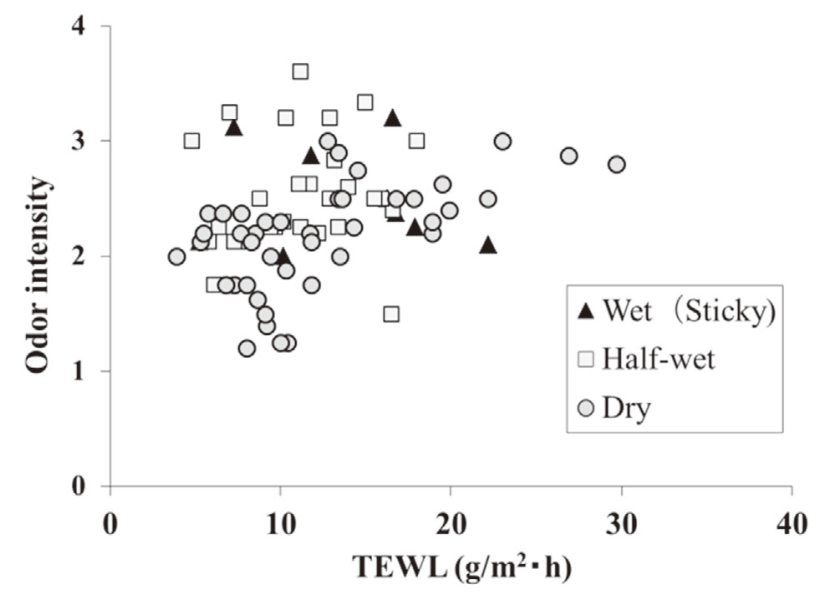

Fig.-3 Correlation between odor intensity and the axillary TEWL value.

${ }^{* *} p<0.01,{ }^{*} p<0.05$.

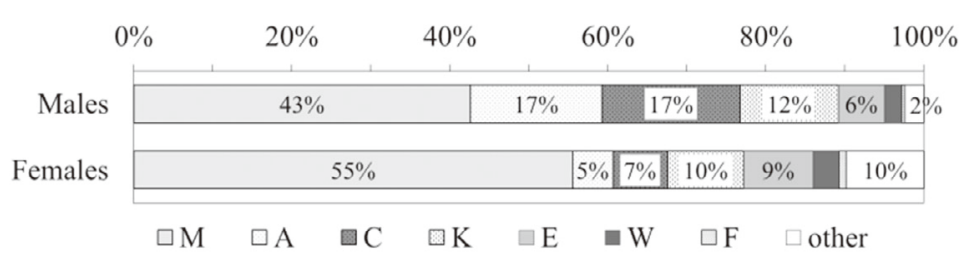

Fig.-2 Classification of axillary odor qualities obtained from 20to 29 -and 40 -to 49 -year-old subjects.

臭タイプは $\mathrm{M}$ 型（ミルク様）であったが， M 型の割合は 男性よりも女性で高かった。男性で M 型に続いて A 型 (酸様)，C 型（カレースパイス様）の割合が高いが，女性 はこれら 2 タイプの割合が低く, 特に $\mathrm{A}$ 型は $\mathrm{K}$ 型（カビ 様）や $\mathrm{E}$ 型 (蒸し肉様)，C型よりもさらに低いことが明 らかになった。

\section{3. 女性における腋臭強度の特徵}

\subsection{1. 腋臭強度と腋窩肌特性の関係}

女性の腋臭強度と腋窩の TEWL 值の関係を検証した。 腋臭強度と腋窩の TEWL 值は弱い正の相関関係が認めら れ，腋窩の TEWL 值が上昇すると，腋臭強度が高くなる ことが示唆された（Fig.-3, Table-4）。次に, この結果を, 耳垢性状で確認したところ, 乾燥した耳垢性状を有する群 でのみ, 腋臭強度と TEWL 值に有意な正の相関がみら れ，他の耳垢性状を有する被験者群ではみられなかった (Table-4)。

\subsection{2. 腋臭強度と腋毛処理の関係}

女性の腋臭強度と剃刀（または電気シェーバー）を用い た剃毛頻度の関係を調查した。剃毛頻度を高頻度（ほぼ毎 日から 2, 3 日に 1 回剃毛する, 20 名), 中頻度 $(4,5$ 日に
Table-4 Correlation coefficient between odor intensity and the axillary TEWL value in the types of earwax.

\begin{tabular}{lrc}
\hline \multicolumn{1}{c}{ Type } & \multicolumn{1}{c}{$r s$} & $p$ Value \\
\hline All & 0.40 & $<0.01$ \\
\hline Wet (sticky) & -0.10 & 0.78 \\
Half-wet & 0.23 & 0.22 \\
Dry & 0.57 & $<0.01$ \\
\hline
\end{tabular}

1 回から 2,3 週間に 1 回する, 28 名), 低頻度（1 カ月に 1 回以下寸る, 33 名）の 3 群に分け, 腋臭強度の比較を行っ たところ， 3 群間の腋臭強度に有意な差は認められなかっ た（Table-5）。また，エステティックサロンや医療機関で の脱毛処理経験の有無で被験者の腋臭強度の比較を行っ た。脱毛処理経験の有無がほぼ同数であった 20 歳代にお いて, 脱毛処理経験が有る群 14 名と無い群 15 名の平均腋 臭強度に有意な差は認められなかった（Table-6）。また， 全年代に扔ける脱毛経験の有無（経験有り群 20 名, 経験 無し群 55 名）に押いても，2 群間に有意差は認められな かった。 
Table -5 Axillary odor intensity and TEWL value in shaving frequency.

\begin{tabular}{lcc}
\hline Frequency & $\begin{array}{c}\text { Odor intensity } \\
(\text { mean } \pm \text { S.D. })\end{array}$ & $\begin{array}{c}\text { TEWL value } \\
(\text { mean } \pm \text { S.D. })\end{array}$ \\
\hline High & $2.3 \pm 0.37$ & $11.9 \pm 5.8$ \\
Middle & $2.5 \pm 0.44$ & $12.5 \pm 6.2$ \\
Low & $2.4 \pm 0.59$ & $11.9 \pm 3.9$ \\
\hline
\end{tabular}

Table-6 Axillary odor intensity and TEWL value in depilation treatment.

\begin{tabular}{lcc}
\hline $\begin{array}{c}\text { Depilation } \\
\text { treatment }\end{array}$ & $\begin{array}{c}\text { Odor intensity } \\
(\text { mean } \pm \text { S.D. })\end{array}$ & $\begin{array}{c}\text { TEWL value } \\
(\text { mean } \pm \text { S.D. })\end{array}$ \\
\hline Experienced & $2.3 \pm 0.34$ & $11.6 \pm 5.3$ \\
Inexperienced & $2.3 \pm 0.42$ & $10.6 \pm 3.4$ \\
\hline
\end{tabular}

次に剃毛頻度と TEWL 值の関倸を調査した。同様に剔 毛頻度を 3 群に分け，TEWL 值の比較を行ったが，3 群間 に差は認められなかった（Table-5）。また, 20 歳代を脱毛 処理経験の有無で 2 群に分け, TEWL 值の比較を行った が，群間に有意な差は認められなかった（Table-6）。

\subsection{3. 腋臭強度と出産経験の関係}

女性の腋臭強度と出産経験の関係を調查した。年齢に伴 い, 出産経験が有る被験者が増えることから，本解析は， 出産経験の有無が同数程度存在する 30 歳代のデータでの み行った。

腋臭強度と出産経験の関係を調査すると, 出産経験が有 る群 9 名と, 無い群 7 名の平均腋臭強度はそれぞれ, $2.8 \pm$ $0.55,2.4 \pm 0.53$ (mean \pm S.D. ) であった。この 2 群間に腋 臭強度の有意差は認められなかった。しかし, 出産経験と TEWL 值の関係を調べたところ, 腋窩, 上腕内側部いず れにおいても, 出産経験が有る群は無い群と比較して, 有 意に TEWL 值が高かった（Fig.-4）。

\section{4. 考察}

これまでの日本人男性を対象にした腋臭研究に加え，日 本人女性を対象とすることで, 現代日本人の腋臭強度や臭 気タイプといった腋臭特性を把握することが可能になっ た。

本研究に㧈いて, 日本人女性の腋臭強度は, 男性よりも 低いことが明らかになった。女性は，発汗量4) や皮脂分泌 量) が男性よりも少ないことがこれまでに報告されてい る。このことから, 皮虚常在菌により代謝され発生した臭 気を有する成分が，男性と比較し女性では少なくなり，結 果的に腋臭強度の差が生じたのではないかと考える。ま た，女性の腋窩面積は男性と比較して小さいこと，さらに

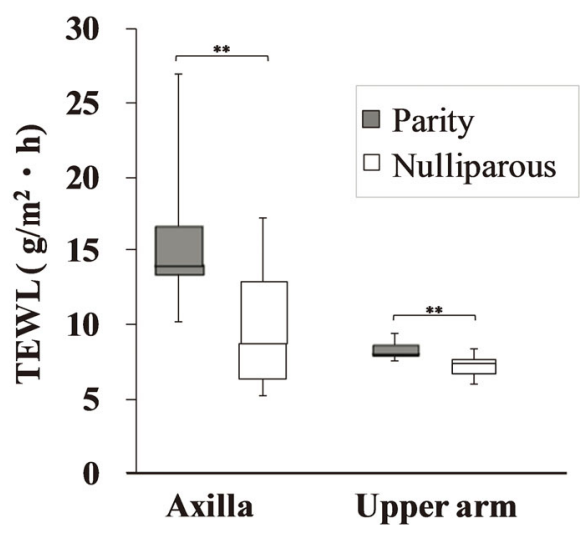

Fig.-4 Comparison of TEWL value between parous and nulliparous subjects.

${ }^{* *} p<0.01$.

腋毛の影響が少なく皮膚常在菌の生息面積が小さいこと が，腋臭強度の低さに反映した可能性がある。

また，臭気タイプの分類において，日本人女性の腋臭の 臭気タイプは, 日本人男性と比較すると $\mathrm{M}$ 型（ミルク様） が多く, A 型 (酸様) やC 型（カレースパイス様）が少 ないことを見出した。男女で臭気夕イプの分布が異なる原 因の詳細は不明であるが, 腋臭強度に差があることが一つ の要因ではないかと考える。女性の発汗量や皮脂分泌量が 少ないことが起因して, 臭気タイプの多様性が男性と比較 して少ない可能性がある。

$\mathrm{C}$ 型， $\mathrm{K}$ 型（カビ様）は臭気の特徵から，いずれも腋臭 症に関連する臭気タイプであると考えている。腋臭症と耳 垢性状の関係はすでに報告がなされており ${ }^{3)}$ ，耳垢性状に よる腋臭症の簡易判断が一般的に行われている。溶けた キャラメル状の耳垢性状を呈する被験者は C 型, $\mathrm{K}$ 型の 臭気タイプに分類されると考えられる。本試験に弤いて, 耳垢性状が溶けたキャラメル状であると申告した男性被験 者 8 名の平均腋臭強度は $3.5 \pm 0.75$ (means \pm S.D.) であり,

7 名が C 型, K 型を有していた。一方，9名の女性被験者 が溶けたキャラメル状の耳垢であると申告したが, 平均腋 臭強度は $2.5 \pm 0.45$ (means \pm S.D.) であり, 約半数の 4 名 のみが $\mathrm{C}$ 型， $\mathrm{K}$ 型を有していた。今回の試験では該当者 が少なかったため断定はできないが，日本人女性におい て, 耳垢性状のみで腋臭症は判断できないことが示唆され た。

女性の日常的な腋毛処理は, 腋窩肌状態を変化させ, 腋 臭強度や臭気タイプが変化するのではないかと仮説を立て た。しかし, 腋臭とカミソリによる腋毛の処理頻度やエス テティックサロン・医療機関での脱毛経験との間に関係を 見出すことができなかった。このことから, 腋臭強度と腋 
窩肌のダメージには関連がないと考える。一方で, 腋臭強 度と腋窩肌の TEWL 值に相関が認められ，これは耳垢性 状が乾燥している群でのみ認められる現象であった。さら に, 腋窩および上腕内側部の TEWL 值は, 出産経験の有 る群で有意に高くなる現象が認められた。腋臭強度は TEWL 值との関係が示唆された一方で，TEWL 值は腋毛 処理に関係が認められなかったこと, 出産経験との関係が 示唆されたことから，本法で得られた腋窩の TEWL 值か らは二つの考察ができると考える。一つ目は，今回関連を 調査した剃刀での剃毛や光やレーザーによる脱毛処理が腋 窩肌にダメージを与えているのではなく，今回調査を行わ なかった月経周期，ホルモンバランス，汗中の成分等が要 因で，腋窩肌がダメージを受け，腋臭強度と関連する可能 性である。二つ目は，TEWL 值は腋窩肌のダメージを反映 しているのではなく，出産などを理由の一因とした，体の 代謝の変化により上昇した不感蒸泄が腋臭強度に関係して いるのではないかと考えた。いずれにおいても現段階で腋 臭強度に TEWL 值がどのようなメカニズムで関連してい るかは不明であるが，女性の腋臭ケアには TEWL 值の制 御が鍵であることが示唆された。

\section{5. 結 論}

日本人女性の腋臭を嗅覚評価したことで，女性は年齢に 伴う腋臭強度の変化が認められないことや, 男性と比較し て臭気タイプの多様性が少ないことを見出した。さらに，
腋臭強度に関連する因子として, TEWL 值を見出した。し かし，女性の腋臭特性には，加齢変化のみでは説明できな い，不明瞭な点が多く残されている。これは，女性は男性 と比較し, 月経・出産など, 体の変化がダイナミックであ ることが理由の一つであると考えている。女性の腋臭ケア には, 体臭科学的な観点での理解のみならず, 皮膚科学的 観点での理解, さらには体の変化を理解することが重要で ある。今後, 男性との腋臭強度の差をもたらす要因の解明 や, 臭気夕イプの分布の違いが生じる理由の追究に取り組 み, 女性の腋臭に適応したデオドラント製品の上市や腋臭 ケア習慣の提案を通して，体臭に対する悩みを解決してい きたいと考える。

\section{引用文献}

1）金関丈夫 著, 大林太良 編, 新編 木馬と石牛 わき くさ物語, 岩波文庫, 1996, p.197-215

2）志水弘典, 原 武史, 占部 駿, 三浦正彰, 山本学 志, 栗山健一, 辻野義雄, 藤原延規, 第 20 回にお い・かおり環境学会講演要旨集，112-113，2007

3) M. Nakano, N. Miwa, A. Hirano, K. Yoshiura, N. Niikawa, BMC Genet., 10, 42 (2009)

4) T. Ichinose-Kuwahara, Y. Inoue, Y. Iseki, S. Hara, Y. Ogura, N. Kondo, Exp. Physiol., 95, 1026-1032 (2010)

5) 光井武夫 編, 新化粧品学 (第二版), 南山堂, 2001, p. 18 